\title{
ESTABLISHING A SERVICE CHANNEL: A TRANSACTION COST ANALYSIS OF A CHANNEL CONTRACT BETWEEN A CRUISE LINE AND A TOUR OPERATOR
}

\author{
Irene C.L. Ng, Ph.D.
}

29 March 2005

Forthcoming in the Journal of Services Marketing, Volume 21, No. 7, (2006)

Irene $\mathrm{Ng}$ is Lecturer in Marketing at the School of Business and Economics, University of Exeter (U.K.),

Contact Information: School of Business and Economics, University of Exeter, Streatham Court, Rennes Drive, Exeter EX4 4PU, United Kingdom Tel: +44 (0) 1392 263250, Fax: +44 (0) 1392 263242, Email: irene.ng@exeter.ac.uk 


\section{ESTABLISHING A SERVICE CHANNEL: A TRANSACTION COST ANALYSIS OF A CHANNEL CONTRACT BETWEEN A CRUISE LINE AND A TOUR OPERATOR}

\begin{abstract}
Services marketing literature treats the distribution of services as distributing service delivery, as opposed to service sales. Yet, many services are not delivered at the time of the sale, and the firm is selling a promise that the service will be delivered at some future time. This paper shows that this advanced selling has serious transaction cost implications to the firm and a potential intermediary.

Through a case study, and using a transaction cost approach, a contract between a cruise line and a tour operator is analyzed. The results show that service intermediaries aren't able to take inventory and are unable to demonstrate their commitment. Consequently, both parties would be unwilling to establish a contract. However, commitment can be achieved through the intermediary investing in relationship-specific assets that it could recover, subject to performance. Similarly, the firm could pledge its capacity for its investment in the specific assets. Such a mechanism aligns the interests of both.
\end{abstract}

Keywords: Services, Transaction cost, Distribution, Advanced Selling, Tourism, Asia

\section{INTRODUCTION}

Traditionally, literature on transaction costs and channel contracts have focused on firms dealing with goods. Little attention has been devoted to the analysis of channel contracts between service firms and their intermediaries, as well as the issues faced by the parties. Although service firms face similar transaction cost problems, the unique characteristics of services serve to amplify the problems further.

In order to better understand service channel contracts, this paper will study a particular contract between an Asian cruise operator and a tour operator through archival records. This channel contract is interesting for a few reasons. First, it highlights the practical as well as theoretical difficulties encountered in contracting between a service firm and its intermediary. Second, it shows how the threat of potential opportunistic behavior of service intermediaries can be reduced even though, as a service intermediary, it is not able to hold inventory. Third, the firm, as a singlevessel cruise operator, is a small-tomedium enterprise (SME), and is thus limited in resources as well as its choice of governance structure. The channel contract and the procedures embedded within, illustrate how service capacity can be used to augment a SME's limited resources. In addition, the paper shows how the SME installed various control

Ng, Irene C.L. (2006), "Establishing a Service Channel: A Transaction Cost Analysis of a Channel Contract between a Cruise Line and a Tour Operator," Journal Of Services Marketing, Volume 21, No. 7 
mechanisms into the contract to reduce potential opportunism and perceived purchase risk by its intermediaries. Finally, the strategically designed contract can even gain intermediaries' commitment to accelerate market development efforts.

The paper begins by conducting a literature review on transaction cost theory and its implications in the service context. The industry overview and the profile of Asiatic Cruise Line follows. The channel contract is then presented, together with analyses of some of the features in the contract. The paper concludes with some summary remarks.

\section{LITERATURE REVIEW}

The study of channel design and contracts is historically rooted in transaction cost theory, following the literature inspired by Coase (1937) and further developed by Williamson (1989). The general problem addressed is how to conduct exchange between channel members whose objectives are only partially convergent (Bergen, Dutta and Walker, 1992; Ouchi, 1979).

According to transaction cost economics (TCE) literature, the criterion for efficient channel design and contracts is to minimize transaction costs (i.e. the intangible costs of running and managing a channel) (cf. Bello and Lohtia, 1995). Such costs arise from impediments in reaching and enforcing agreements within a channel and are associated with activities such as bargaining, contracting, monitoring performance, and activities that are not directly productive but which are engaged in only as a consequence of a need to coordinate activities among transactions. Transaction costs also include the cost of acquiring market information; costs arising from environmental uncertainty, and particularly for this paper, the cost of opportunism (see Rindfleisch and Heide, 1997 for a good review on transaction cost analysis). This means that if the optimal choice of a channel contract has been established with an independent agent, often involving relationshipspecific investments, parties may act opportunistically after the contract has been formed (Joskow, 1987).

Opportunistic behavior can manifest itself in two forms (Masten, 1996). The first type of opportunism usually entails a transgressor using certain 'loopholes' within a contract in such a way that does not actually breach the terms of the contract, but to take advantage of terms in the contract that are ill defined or difficult to enforce. Such behavior, considered a moral hazard to economists, often exploits the fact that the cost of maintaining the contract to the other party, even with the transgression, is lower than not having the contract at all (cf. Masten, 1996).

The second form of opportunism arises from the fact that when an initial contract with certain specific investments that bind parties are in force, the party who perceives himself in a stronger position may renegotiate the terms in such a way that holds the other party "ransom" (Masten, 1996; Williamson, 1985).

Ng, Irene C.L. (2006), "Establishing a Service Channel: A Transaction Cost Analysis of a Channel Contract between a Cruise Line and a Tour Operator," Journal Of Services Marketing, Volume 21, No. 7 
Notwithstanding the hazards of contracting and the imperfections in the ability of parties to protect themselves, channel contracts with independent middlemen still represent the norm in global trade (Bello and Lohtia, 1995). This is because the use of non-integrated channels (independent agents or distributors) often provides a relatively easier mode of entry into a foreign market (Root, 1987). These intermediaries possess strong knowledge of the local market and are able to provide sophisticated marketing services (Clasen, 1991).

Given the potential opportunism threat, establishing efficient channel contracts for goods firms pose a challenge in itself and academic literature has dealt with it extensively. Indeed, normative research on channels and transaction cost economics has concentrated on goods firms. Little academic attention has been devoted to the development of service channels contracts. This is despite some TCE studies showing that international entry mode choice are affected differently for goods and service firms in transaction cost theory (Erramilli and Rao, 1993; Murray and Kotabe, 1999). Perhaps the reason for this is because the unique characteristics of services - its intangibility, inseparability, perishability and heterogeneity make it difficult to relate to how the "distribution" of a service can be accomplished (Light, 1986). Hence, there are currently very few studies exploring the specificities of services and synthesizing them with transaction cost economics especially with regard to the process of how service contracts are established. Compounding this difficulty is the likelihood that obtaining data on contracts a deliberation is small, as they tend to be confidential and sensitive. Yet, this synthesis is necessary because while conventional service literature informs us that services exhibit unique characteristics, such descriptions would not be useful unless translated into some meaningful insights that assist firms in contractual decisions.

The intangibility of a service create problems for the marketer as not only potential buyers are not able to see or touch it before consumption, channel intermediaries may also not be able to convey the idea and the quality of the service to the consumer satisfactorily. The role of channel intermediaries in selling services therefore tends to be more complicated than the physical distribution of goods. As Stone (1990, pg. 80) puts it, "How can you rely on the agency to position your product properly, particularly when perceptions and promise are the essence of selling?"

The inseparability of many services from production and consumption may imply that direct sale is the only option and channel intermediaries are not required. Regrettably, such an option will severely limit the service firm's ability to market its service offerings elsewhere. To overcome this limitation, many tourism services distribute a tangible representation of the service (Ng, Wirtz and Lee, 1999). In this respect, channel intermediaries

Ng, Irene C.L. (2006), "Establishing a Service Channel: A Transaction Cost Analysis of a Channel Contract between a Cruise Line and a Tour Operator," Journal Of Services Marketing, Volume 21, No. 7 
often do not distribute the actual service but a tangible representation of a promise that the service will become available for consumption at some future time or date, such as that of an airline ticket, a hotel voucher, meal coupons or a cruise ticket. Transaction cost implications on the distribution of a promise has still not been adequately dealt with in academic literature.

The heterogeneity of services often results in the lack of standardization in the service delivery process. This may sometimes result in dissatisfied customers and thus strain the relationship between independent channel intermediaries and the service firm. Consequently, many service firms resort to vertical integration to solve the marketing problem (Seaton and Bennett, 1996). However, due to the intangibility of services, perceived risk of purchase is higher (Murray and Schachter, 1990). To reduce that risk, consumers usually look for more information (Lutz and Reilly, 1973). This is usually the case for tourism services where the agent's role is to provide customers with sufficient information to facilitate travel purchase decisions (Seaton and Bennett, 1996). In this respect, when a vertically integrated channel is used to communicate with customers, the information can be perceived as biased and customers may choose not to purchase from the intermediary concerned (Seaton and Bennett, 1996). Accordingly, the use of independent intermediaries still prevails in the marketplace.

Perishability of services also creates potential problems. In the effort to maximize yield and reduce unused capacity, many service firms sell in advance ( $\mathrm{Ng}, 2004)$. By price discriminating through advanced selling, firms practice yield management with time-based pricing and even overbooking (Lee and $\mathrm{Ng}$, 2001). Channel intermediaries may find that the service may not be available at certain times and prices may vary, resulting in confusion, repeated bargaining and therefore higher transaction costs for channel participants and the service provider.

Similar to a goods firm, the central issue to the contracting difficulties between a service firm and its agent is also brought about by potential intermediary opportunism. (Light, 1986; Stone, 1990). However, the threat of potential intermediary opportunism is greatly enhanced for services due to several reasons. First, since services are inseparable, many firms have taken to distributing promises. This means that intermediaries run a risk that a promise may not be fulfilled by the firm, for reasons that may or may not be within the principal's control. Second, because of the heterogeneity of services, channel intermediaries also have to face some uncertainty with regards to the quality of the service delivered. Such uncertainties weigh heavily on the channel contracts primarily due to bounded rationality.

Bounded rationality refers to the fact that although individuals act in a rational manner, their rationality is bounded by their limited understanding of the issues involved, the inability to foresee the future, the

Ng, Irene C.L. (2006), "Establishing a Service Channel: A Transaction Cost Analysis of a Channel Contract between a Cruise Line and a Tour Operator," Journal Of Services Marketing, Volume 21, No. 7 
insufficient expertise in the matter and/or a high cost of time (search costs) (Simon, 1957, 1961). Bounded rationality therefore prevents a contract from being complete, since contracting parties are not able to foresee all future events, nor are they able to provide for them in the contract. Where bounded rationality exists amongst the contracting parties, greater uncertainty increases the fear of opportunistic behavior and thus undermines the ability of parties to write more efficient contracts (Bello and Lohtia, 1995; Williamson, 1991).

While service intermediaries can claim to have higher risks in selling services because of the heterogeneity and perishability problem, these may be partially resolved by the service firm through a reputation of good quality (reduced risk with heterogeneity) and providing guarantees that a promise of a service will be delivered.

The more severe problem arises from the intangibility and the inseparability of services as these characteristics result in the intermediaries themselves being unable to hold inventory as a demonstration of their commitment (see Bateson, 1995). Where there are contractual obligations to ensure the fulfillment of a promise (e.g. a ticket or a voucher) and reasonable reputation to ensure satisfactory service quality, the burden of risk in the channel contract becomes asymmetrical. Service firms often hold almost all of the financial risk in ensuring that a service is delivered. This is unlike their counterparts in goods where many retailers assume some part of the risks by taking in stock (Goodall and Ashworth, 1988; Middleton, 1994).

The inability of a service intermediary to hold inventory has severe transaction cost implications. It is apparent that the intermediary is unable to provide a credible commitment to a service firm as an assurance of its ability to expend significant marketing efforts to promote its service (often, to obtain higher margins). This inability results in intermediaries having no incentives to stay committed to a particular service provider (cf. Seaton and Bennett, 1996). Consequently, the service firm is less likely to invest in any relationship-specific assets and the fear of potential opportunistic behavior becomes omnipotent in negotiating channel contracts.

Such fear of opportunistic behavior is evident in the tourism industry where through analyzing this case, the hotels commonly issue contracted rates for their rooms to multiple agents (and often multiple rates too) without much commitment from agents in return. Consequently, agents sell on an as-and-when-thereare-enquiries basis, and often do not go out of their way to aggressively promote the tourism product. Although the lack of commitment from both parties serves to reduce the transaction costs from potential opportunism, it is highly inefficient and unproductive and usually impedes market development for many tourism service offerings.

Opportunistic behavior is therefore costly. To the extent that parties can try to devise contracts that

Ng, Irene C.L. (2006), "Establishing a Service Channel: A Transaction Cost Analysis of a Channel Contract between a

Cruise Line and a Tour Operator," Journal Of Services Marketing, Volume 21, No. 7 
reduce the probability or costs of conflicts, the gains available to redistribute between them rise tremendously (Jeuland and Shugan, 1983). However, the problem to constrain opportunism places great demands on bounded rationality (Williamson, 1985).

From this study, it was found that many tourism service firms take the path of least resistance - by not committing to any binding contract seems more prudent than to be a victim of an opportunistic agent. Without a credible commitment, many principals do not feel assured to invest in assets required in building the channel relationship, as it believes the agent will act opportunistically once the market is established. This is particularly so for SMEs where resources are limited (Donald et al, 1991), as the potential backlash (opportunistic behavior of agents) further depletes resources.

Paradoxically, the SMEs themselves have a greater need for channel intermediaries. This is because, given the resource disadvantage, many SMEs are unable to mount a large-scale market development exercise. To distribute their good or service, there is usually a heavier reliance on intermediaries. This reliance is even greater for tourism SMEs where the market is often found in the same geographical area. Furthermore, since resource limitation is a major problem for an SME, the choice of governance structure is likewise limited and vertical integration is often not an available option.
Notwithstanding the challenges posed by the unique characteristics of services, independent service intermediaries do exist, especially in the marketing of tourism services. These intermediaries serve to fulfill the role of information providers, giving customers a host of purchase options in tourism services, mostly provided by other companies, and hence are often referred to as 'agents' (Foster, 1985; Burkart and Medlik, 1981). Indeed, travel agents and tour operators in the tourism industry perform a major role in service distribution. For example, in the cruise industry in 1994, sales by travel agents and tour operators account for $97 \%$ of cruise sales onboard all ships (Godsman, 1994).

The arrival of the Internet brought considerable changes in the way tourist products are marketed. Online activities now form part of many marketing activities conducted across multiple channels (Peterson, Balasubramamiam and Bronnenberg, 1997). Many scholars have studied the advantages of the Internet for businesses (e.g. Verity and Hoff, 1994; Qualch and Klein, 1996) and it was clear that it created access to segments that were poorly served before and also allowed businesses to increase efficiency and effectiveness. Indeed Pitt et al (1999) identified three effects of the Internet i.e. eliminate barriers cause by distance, allowing virtual businesses to operate 24 hours a day, 365 days a year, and making physical locations less relevant. As a result, there were compelling arguments for disintermediation, since the Internet is

Ng, Irene C.L. (2006), "Establishing a Service Channel: A Transaction Cost Analysis of a Channel Contract between a Cruise Line and a Tour Operator," Journal Of Services Marketing, Volume 21, No. 7 
able to directly link customers and suppliers. Yet, it is becoming apparent that there exist many customers who do not want to deal with the problems of contacting multiple suppliers, and are prepared to pay for the expertise and convenience of travel agents and tour operators (Block and Segev, 1996). Furthermore, the Internet may not give the individual the best price, even if more reservations are undertaken through it, as the individual bargaining power is less than that of a consolidator such as a tour operator or travel agent (Bloch, et al, 1996; Wynne et. al, 2001). Thus, tour operators and travel agents who operate online, e.g. Expedia, Travelocity have better chances in terms of offering customer value online and would still be a force to reckon with in the future (Wynne et. al., 2001). Indeed, as online sales increase, tour operators' bargaining powers are expected to become higher, thereby increasing the risk of opportunism.

Extensions of Transaction Costs Economics (TCE) literature have advised contracting parties to deploy control mechanisms to manage contracting parties' potential opportunistic behavior with the objective of reducing governance costs (Anderson, 1985; Heide and John, 1988; Klein, Frazier and Roth, 1990; Lal, 1990). These include qualification procedures (Heide and John, 1990), credible commitments (Anderson and Weitz, 1992) and monitoring (Lal, 1990). However, within the context of services there is hardly any literature on how governance costs can be reduced, especially in light of the unique characteristics of services. While qualification and monitoring procedures can be put in place, the issue of credible commitment remains unresolved.

This study analyzes a contract between a cruise line and a tour operator from archival records and structured interviews of the decision makers within the firms. Through this study, we offer a better understanding of the contracting difficulties examined in the literature review and offer possible solutions to the obstacles faced. Similar research has been conducted to better understand contracting decisions in services (e.g. Dahlstrom and Nygaard, 1999). However, contracts are often confidential and data from the deliberation process is often scant. Indeed, most studies would rely on the analysis of agreements (e.g. Brouthers and Brouthers, 2003) and draw conclusions based on the contractual choices.

\section{METHODOLOGY}

The approach adopted was that of a case study through an analysis of minutes of meetings, archival notes, articles and reports by the firms' executives, brochures, secondary reports and the actual contract between the two parties over the course of 1995. These documents were supplemented by interviews with the firms' executives and the CEO of the firm. Despite the progress of time, it is my opinion that many of the issues surrounding the situation then are still relevant today. The rationale

Ng, Irene C.L. (2006), "Establishing a Service Channel: A Transaction Cost Analysis of a Channel Contract between a Cruise Line and a Tour Operator," Journal Of Services Marketing, Volume 21, No. 7 
of the case study, therefore, is to analyze the contract, environment and decisions and draw out the theoretical issues surrounding the establishment of service channels. This case is viewed as a particularly strong manifestation of the issues and is therefore deemed worthy of study. Due to confidential agreements, the actual names of the parties cannot be divulged.

\section{FINDINGS}

\section{INDUSTRY HISTORY}

At the time of this case (1995), global cruise industry statistics indicated that there were 123 ships in operation under the management of 40 cruise lines. These totaled just over 100,000 beds a day and a passenger capacity of 5.428 million per year based on individual ship's itineraries and schedules. Projected numbers showed that 1996 would see 4.876 million passengers resulting in industry occupancy levels reaching close to $90 \%$ and an estimated sales revenue of USD10 billion (Anonymous, 1995). With forecasted loads at close to $90 \%$, major cruise operators were already making plans to increase supply of cruise berths.

The strong growth of cruising passengers in North America created the feeling that the Caribbean was getting crowded (Frey-Gaynor, 1993). To diversify the number of cruise offerings, many North American cruise lines started to look at the Far East as a potential cruising region (Frey-Gaynor, 1993). Unlike the Caribbean cruise industry that held almost $67 \%$ of the market share in the total global cruise industry, the Far East (Asian Region) held only 2\% (Anonymous, 1995). However, North American cruise lines that have already placed vessels in the Far East on a seasonal basis were starting to plan for a greater presence in this region by offering year-round cruise products (Frey-Gaynor, 1993, 1995). Similarly, others who did not have any cruise itineraries in the Far East were also starting to plan in that direction. In addition, with growing affluence in Asia, many Asian consumers were looking at trying something new. Designing cruises that cater to the Asian market could therefore be a profitable niche.

It was precisely this niche that prompted Lena Ho to form Asiatic Cruise Lines in December 1993, one of the first cruise lines in Southeast Asia to operate a vessel that caters to the Asian market on a year round basis.

After Asiatic was formed, there was an impetus to establish a distribution network of agents. Through the agent network, the domestic market developed rapidly. By early 1995, cruise passenger turnover tripled and direct selling constituted $30 \%$ of sales with the other $70 \%$ sold through agents in Malaysia and Singapore.

Lena Ho was not the only one intending to profit from the niche. Other operators had similar ideas. By 1995, there were a total of 6 cruise operators, including Asiatic, catering to the regional markets of Southeast Asia (Ng, 1995b). These cruise operators, who were referred to as regional cruise operators (as a 
distinction from the foreign cruise operators whose markets originated from either North America or Europe), contributed tremendously to the growth of the industry. Statistics released by the port authority in Singapore showed an increase of $286 \%$ in terms of passenger numbers going through Singapore from 1993 to 1994. Figures in Port Klang (Malaysia) also showed an increase of over 836\% from 1992 to 1993 and $86 \%$ from 1993 to 1994 ( $\mathrm{Ng}, 1995 \mathrm{a})$. The figures showed that some $74 \%$ of the passengers going through its port were passengers from Southeast Asia (Ng, 1995a).

One of the reasons for the unprecedented growth in passenger numbers going through the Southeast Asian ports of Malaysia and Singapore was because the cruises offered by the regional cruise operators were shorter than those operated by their foreign counterparts. Consequently, the turnover of passengers over a given month was higher. The longest cruise offered to the regional markets was only 3 nights long, and although there were a few longer cruises offered, they were not popular. The most popular of the short cruises proved to be the overnight cruises, commonly called "Cruise-to-Nowhere". These were popular because it was a sampling of how a regular cruise would be, and was therefore appealing to the Asian customers, many of whom had never cruised before. Also, a high proportion of cruise income from regional cruise operators was derived on board i.e. in the casino (Ferguson, 1997). Thus, a shorter cruise would enable a more frequent 'turnover' of customers and also reduce the impact of unsold capacity, since any excess capacity would be for the duration of one night only, instead of multiple nights.

Like the other operators, Asiatic also operated short cruises catering to the regional markets of Malaysia, Singapore and Thailand. Similar to the rest, the line depended a great deal on income from the casino. However, the company had a long-term plan to ensure a mix of both gaming passengers (a term used by the line for the segment of the market who was less interested to cruise than to play the tables in the casino) and tourists (the term for the segment that came on board to experience the cruise itself, with all its attractions on board).

\section{ASIATIC CRUISE LINE}

Asiatic Cruise Lines, a Malaysian company based in Kuala Lumpur, was a SME operating a single vessel cruising in the Southeast Asian waters. The longterm plan of the company was to own a fleet of cruise vessels operating in Southeast Asia. Formed in December 1993 by Lena Ho, Asiatic Cruise Lines and their 22 person team introduced their ship $M / V$ "The Asian Princess" in May 1994. The vessel was chartered from a US based company with the intention to purchase her at a later date. She was approximately 8,500 tons, $140 \mathrm{~m}$ long, able to cruise at a maximum speed of 17 knots and was able to sleep 408 passengers in 150 cabins. Classed by

Ng, Irene C.L. (2006), "Establishing a Service Channel: A Transaction Cost Analysis of a Channel Contract between a Cruise Line and a Tour Operator," Journal Of Services Marketing, Volume 21, No. 7 
Lloyds U.K., the vessel was built in 1966 but was extensively refurbished over the years. Her facilities included a show lounge, karaoke lounge, disco, gift shop, photo shop, pool, hair salon (with massage services), kids play area, clinic/hospital and of course, the casino. The officers and crew made up the 205 crew contingent on board. The vessel's home port was Port Klang in Malaysia although "The Asian Princess" called at various other ports of Penang (Northern Malaysia), Phuket (Thailand) and Langkawi (Northern Malaysia).

Since Asiatic was a SME, its resources were limited and the company was not able to purchase sophisticated cruise reservation systems from established companies in the West. However, Asiatic Cruise Lines developed an in-house computerized cruise reservation system, with auto-ticketing, computerized fare codes to handle multi-tier fares, structured reporting and generation of passenger name references (PNRs).

With a computerized reservation system, Asiatic was able to perform automatic and remote ticketing, control fares, provide automated reporting and adept at handling both bulk wholesale and retail reservations. It was through the development of this system that enabled Asiatic to penetrate the travel agent network and expand its distribution in Malaysia and Singapore as the system was able to handle various sophisticated levels of agent and corporate bookings and requests.
Furthermore, the company was also able to handle more complicated itineraries to improve their per diems (a common industry term that refers to the amount paid per passenger per night). This would include offering a series of cruises-to-nowhere to two geographical segments of the Malaysian market. Asiatic cruises to nowhere were available out of Penang (a port in the northern part of Malaysia) as well as Port Klang (the main port of Malaysia, some fifty kilometers out of the capital, Kuala Lumpur). Planning the ship's itinerary such that she called into Penang on alternate weeks to do a series of overnight cruises and cruises to Phuket (in Thailand), Asiatic had the benefit of a more diversified portfolio by having a domestic market consisting of two geographical markets that had the highest population density in Malaysia. Also, since the vessel called at 3 ports it aimed to have a more stable itinerary that could be marketed on a longterm basis to foreign tourists.

In 1995, Asiatic had five main cruise products. The cruise-tonowhere from Port Klang, one way cruise from Port Klang to Penang (frequently termed as the positioning cruises since the vessel was being positioned in Penang to serve that market), Penang to Phuket (with return) cruise, cruise-to-nowhere from Penang, and the positioning cruises from Penang back to Port Klang. A typical week's itinerary for the vessel can be seen from Table 1 below. From this itinerary, Asiatic also sold cruises from Port Klang to Phuket and Penang, but passengers would need

Ng, Irene C.L. (2006), "Establishing a Service Channel: A Transaction Cost Analysis of a Channel Contract between a Cruise Line and a Tour Operator," Journal Of Services Marketing, Volume 21, No. 7 
to disembark at Penang instead, since the vessel would take in one or two more overnight cruises before returning to Port Klang.

$<$ Take in Table 1 here $>$

$<$ Take in Figure 1 here $>$

Positioning cruises were difficult to sell in the Malaysian markets, because the passenger would have to make alternative arrangements to return (i.e. by rail or by flight). Since the positioning cruises were only one night in duration, many passengers considered the duration to be too short to go through the trouble of making alternative arrangements of returning. Yet, Asiatic was not prepared to give up either Penang or Port Klang markets by having the vessel permanently sailing on itineraries from only one homeport since having twin markets offered greater stability and better loads. Often, the positioning cruises would only have some twenty passengers on board. There was tremendous excess capacity and a solution had to be obtained soon.

In late 1994, Asiatic embarked on an ambitious program to market the positioning cruises, not to its primary market of Malaysia, but to other Asian markets of Japan, Taiwan, Korea, Hong Kong and Thailand. In partnership with Malaysian Airlines (the national flight carrier of Malaysia), Creative Tours (Ho's own company) and a few hotels, they launched the first FlyCruise-Tour (FCT) in the region. Twenty-five tour operators were invited, on a complimentary basis, to fly to Malaysia, tour Kuala Lumpur (the capital of Malaysia), cruise to Penang on the vessel (one way) and tour Penang before returning to their original destination. This invitation served not only to introduce "The Asian Princess" to some of the top tour operators in these countries but also to allow them to go through exactly the fly-cruise-tour itineraries as their passengers would, if the program were adopted and sold in their home country.

However, despite aggressive attempts on the part of the company, selling the cruises to these new external markets were slow. The external markets were many in numbers, geographically far apart, and above all, uneducated about going on a cruise. There was a need to develop channel contracts such that the cruises can be marketed effectively within these markets. However, the agents were only prepared to promote the cruises if Asiatic was willing to fund travel agent training, consumer education and marketing. With limited resources, Asiatic had to be selective in the market it chose to develop. Furthermore, there was no guarantee that the external agent would be committed to aggressively promote the cruises once the funds have been spent. The fear of opportunistic behavior is once again prevalent.

Nevertheless, determined to accelerate its market penetration efforts overseas, Asiatic attempted to establish a channel contract with TourAsia, an Australian travel agent and tour operator.

Ng, Irene C.L. (2006), "Establishing a Service Channel: A Transaction Cost Analysis of a Channel Contract between a Cruise Line and a Tour Operator," Journal Of Services Marketing, Volume 21, No. 7 


\section{THE CONTRACT}

The fundamental nature of a contract is to progress beyond mere promises in such a way that parties entering into a contract would hope to reduce any mutual inclination towards opportunism (Masten, 1996). Since both parties did not wish to waste their time on contracts that were of little use, transaction cost issues were kept on the forefront of negotiations and both sides were determined to obtain a solution.

The Australian market was first introduced to Asiatic by Ben Tan, the managing director of TourAsia, a large tour operator based in Melbourne, Australia, which specialized in tours to Asia. The Australian market was attractive to Asiatic because it had a large population of retirees that were affluent. As this segment of the market had both the time and the money to go cruising, they were considered the ideal market to tap into.

In addition, the Australian market was very attracted to the destinations of Penang and Phuket. The idea was to sell the positioning cruise of Port Klang-Penang-Phuket through a fly-cruise-tour program illustrated in Table 2.

$$
<\text { Take in Table } 2>>
$$

\section{Ensuring partner suitability}

In light of past experiences with overseas tour operators, Asiatic was cautious in dealing with TourAsia. They conducted an extensive study into TourAsia's markets, its current market position amongst tour operators in Australia and the ability of the company to aggressively promote and sell cruising in Asia to the Australian market. Asiatic was particularly impressed with TourAsia's network of agents selling their programs, as well as the sophisticated reservation system TourAsia possessed that allowed them to handle all bookings on their programs. In addition, TourAsia had a track record of successfully introducing new and innovative tourism products to the Australian market. Such a reputation gave Asiatic some assurance on the suitability of TourAsia as a partner since the long-run building of the relationship would be more beneficial than the short-term gains from taking advantage of a contracting partner (see Telser, 1980).

\section{Credible Commitments}

From the viewpoint of the Australian market, Asiatic Cruises offered a completely new product. Going to Asia for a cruise was not a well-known idea in Australia and funds were required to educate the market. In this regard, Asiatic was faced with a few problems. Although it had some funds to spend on external markets, Asiatic was also keen to penetrate other markets besides Australia and did not want to spend too much into a single market.

To develop the market, TourAsia estimated that AUD\$140,000 was required over the first year. A complete 1996 sales and marketing plan to market Asiatic cruises nationwide was proposed and

Ng, Irene C.L. (2006), "Establishing a Service Channel: A Transaction Cost Analysis of a Channel Contract between a Cruise Line and a Tour Operator," Journal Of Services Marketing, Volume 21, No. 7 
accepted by Asiatic. This would include consumer advertisements, product and sales training of front line staff, fax broadcasts, promotions and a host of other marketing activities. TourAsia proposed that the plan should be jointly funded by both companies on an equivalent basis. However, from Asiatic's point of view, they could at most, allocate only AUD $\$ 20,000$ for the Australian market.

Additionally, Asiatic also felt that if they actually expended the funds to develop the market, other cruise lines would take the opportunity to enter the market, once it was developed, by appointing TourAsia as their agent.

From TourAsia's perspective, they were reluctant to fund the whole marketing exercise, as they were of the opinion that Asiatic was the prime beneficiary. A compromise was developed on a $60 \%(A \cup D \$ 84,000)$ $40 \% \quad(A \cup D \$ 56,000)$ basis where Asiatic would fund the higher portion. To accommodate Asiatic's resource constraints, it was agreed that TourAsia would fund AUS $\$ 120,000$ up front for the marketing exercise with Asiatic contributing AUD $\$ 20,000$ cash. To recover Asiatic's balance share of the funds (AUD\$64,000), TourAsia would have to actually sell the cruises and recover the balance from a percentage of the cruise sales sold over the entire year. Since TourAsia's forecasted number of passengers was approximately 5,000 with a minimum cruise of 2 nights per passenger, TourAsia could only recover the full amount of Asiatic's share over the contract duration of one year, if it were able to fulfill its target. Otherwise, the deductions would continue until the amounts were fully recovered. There was no penalty on non-fulfillment of target since it was a new market and the forecasts were also uncertain.

To provide the assurance to TourAsia that the cruises sold would be available, Asiatic consented to contract on a fixed price basis and pledged a fixed capacity so that TourAsia would have a 'free-sale' benefit (a free-sale is an industry term to mean that an agent can confirm a seat/room without referring back to the principal for confirmation on price and capacity availability). This pledge provided the agent with a guaranteed allotment of cabins. Finally, the contract would hand TourAsia total exclusivity to the Australian market.

The contract feature of up-front funding by the agent resolved a few issues, those relating to potential opportunism arising from the intangibility and the inseparability of the service. Whilst TourAsia still did not hold inventory, Asiatic would have had a credible commitment from the agent, since TourAsia would be investing in some relationship-specific assets in the form of funding the marketing exercise. Specific assets are idiosyncratic investments that are specifically designed such that redeploying their use to alternative partners in the contract would render them almost valueless (Bello and Lohtia, 1995; Williamson, 1985). Such is the case for the marketing expenditure proposed by TourAsia.

However, TourAsia's investment in the specific assets is

Ng, Irene C.L. (2006), "Establishing a Service Channel: A Transaction Cost Analysis of a Channel Contract between a Cruise Line and a Tour Operator," Journal Of Services Marketing, Volume 21, No. 7 
only partial. To ensure that there is no reverse-opportunism, Asiatic would have to sink in its share of the marketing exercise. However, taking into consideration the resource limitation of Asiatic, Asiatic's share was partially advanced by TourAsia. This advance was made possible by the fact that the capacity of the cruises has been, in effect sold, through an advanced pledge. Through advanced sale, Asiatic was able to augment its resources. In addition, since TourAsia's recovery of the advance is progressive over the contract duration as sales materialize, it would have an incentive to aggressively promote the cruises, so as to ensure an earlier retrieval of the marketing funds.

Also, a prominent feature in the contract between Asiatic and TourAsia is the fact that a portion of the cruise capacity was used as a pledge. Anderson and Weitz (1992) defined pledges as "actions undertaken by channel members that demonstrate good faith and bind the channel members to the relationship. Pledges are more than simple declarations of commitments or promises to act in good faith. They are specific actions binding a channel member to a relationship."

The contract between Asiatic and TourAsia used the capacity of the positioning cruises as a form of a pledge. This was of paramount importance to TourAsia to counter the threat of potential opportunistic behavior by Asiatic and to ensure the return of the advances. Such a pledge was given to TourAsia in exchange for TourAsia's commitment of expending the marketing funds into the market to promote the Asiatic's cruises. With the pledge, TourAsia could be more assured of Asiatic's commitment to their market. Asiatic, on the other hand, gained the assurance of the agent's investment.

Accordingly, rather than focus the firm's effort on reducing potential opportunism, the focus of both cruise line and agent is now convergent and both have an incentive to work towards a joint surplus maximizing behavior of developing the market to its full potential.

\section{Formalization to control excess} capacity

Asiatic also introduced further safeguards, such as formalization ${ }^{1}$ procedures, which dictate the date when the capacity pledged to TourAsia would be released back to Asiatic within a 'cut-off period' (i.e. the number of days before a service is to be performed). With formalization, transacting parties are more assured of each other's behavior and such predictability fosters the relationship. Research has shown that formalization procedures reduce opportunism and increase the effectiveness of the relationship (Dahlstrom et. al., 1995).

In this contract, the formalization procedures dictated the cut off date of two (2) months before a cruise when the pledged capacity was released back to the cruise line. Since the Australian market often confirmed their travel arrangements more than two months before the onset of travel, such an imposition 
created no problems to TourAsia. By doing so, Asiatic was able to put other potential customers on a waiting list and confirmed them with the capacity released by TourAsia, if they were unable to fill their capacity by the cut off dates. Consequently, even though pledging capacity without a guarantee of sale may risk potential excess capacity, wait-listing potential customers (and agents) who would purchase capacity released after cut off date would substantially reduce that risk while still giving Asiatic the benefits of the pledge.

Finally, both Asiatic and TourAsia were aware that new market development entailed a great deal of uncertainty and complexities, through issues that the contract may not have provided for. Thus, the short contract duration served three purposes.

First, it gave both parties the platform to develop the relationship such that the contract may become 'relational' in character. When parties participate in a more relational contract, the process by which the exchange is facilitated is usually more flexible, with parties preserving the 'spirit ' of the contract rather than the explicit terms (see Lusch and Brown, 1996). Second, if the contract or the market does not work out, both would have shared the risk and would equally be able to walk out of the deal, wiser and without recriminations. Finally, should the market turn out better than expected, no party would be able to hold up the other as the contract would have to be re-negotiated. The benefits of the relationship specific assets would have only been useful during the contract duration. Consequently, Asiatic and TourAsia signed the contract in January 1996.

\section{DISCUSSION}

Normative services marketing literature treats the distribution of services as the distribution of service delivery, as opposed to the distribution of service sales (Lovelock, 2000; Payne, 1993; Zeithaml \& Bitner, 2000). This difference may not be as relevant in goods since it is assumed that the selling and distribution of a tangible good can occur at the same time. However, the same cannot be assumed for services for the following reasons.

First, services often operate with a fixed short-term capacity (cf. $\mathrm{Ng}$, Wirtz \& Lee, 1999). This usually results in services being sold in advance (Ng, 2004; Lee \& Ng, 2001; Shugan \& Xie, 2000; Xie and Shugan, 2001), as the consumers may wish to have the assurance that the service is available at the time they wish to consume it. $^{2}$ There is therefore a meaningful time difference between selling and delivery. Furthermore, the selling of a service in advance may be through an agent or sold directly through a firm (e.g. travel agent as in this case). Since the service is not delivered at the time of the sale, the sale is essentially the sale of a promise that the service will be delivered at some future time. Complicating this promise is the fact that a service is perished immediately upon production and/or consumption and the consumer would not be able to obtain the same service again. ${ }^{3}$

Ng, Irene C.L. (2006), "Establishing a Service Channel: A Transaction Cost Analysis of a Channel Contract between a Cruise Line and a Tour Operator," Journal Of Services Marketing, Volume 21, No. 7 
The advanced sale of the service therefore has serious transaction cost implications to the firm and a potential intermediary.

This paper highlights various practical and theoretical issues that can potentially thwart the development of a service channel contract. It showed that service intermediaries are not able to take inventory and is therefore unable to demonstrate their commitment. Consequently, both parties would be unwilling to establish a contract. This result is consistent with the findings of Brouthers and Brouthers (2003). In their study, they showed that service firms making high asset specific investments preferred wholly owned modes of entry (as opposed to having an intermediary).

However, this study demonstrates that commitment can be achieved through the intermediary investing in relationship-specific assets, such as marketing and promotional funds, that could be recoverable, subject to performance. In other words, the investment of such assets by the intermediary provides two benefits. First, it provides the service firm with a credible commitment from the intermediary. Second, if the monetary value of the assets can be recovered progressively through sales, and within the contract duration, the intermediary would not be at risk from the service firm's potential opportunism since the recovery is in the former's full control. It also provides an incentive for the intermediary to be more aggressive in selling and obtaining an earlier recovery of its funds. As for the service firm, the intermediary's recovery of the specific assets serves also as a fulfillment of its obligations under its contract.

This study also contributes to academic literature in this area through the analysis of the deliberation process that took place in the institution of the contract. Our findings suggest that there is often more than meets the eye when analyzing written contracts and the analysis of written agreements should not be to the neglect of rich and insightful data that could be obtained from the deliberation process.

This case also uncovers an interesting aspect of service firm's ability to realize greater resources through advanced selling. Since a service firm faces capacity constraint, the threat of denying the intermediary the cruise at the time of consumption is real and credible. Furthermore, the cruise that departs at that point in time is no longer saleable. The agent therefore loses any opportunity to obtain revenue from a sale. With a credible threat of capacity unavailability, there is a real value attached to buying the service in advance for the agent. This results in an augmentation of the service firm's resources for specific asset investments in the channel. However, to provide the intermediary the assurance that it will not behave opportunistically, the service firm has not only to invest in specific assets but also to pledge its capacity to the intermediary. 


\section{CONCLUSION}

The topic of sales channels in advance for service firms warrants research attention. There is currently very little research in this area. Even literature that investigates advanced selling have not yet delved into advanced channels. Furthermore, advanced selling literature in services is often in the form of theoretical models. Empirical studies on this phenomenon is still largely absent. This paper aims to illustrate servicespecific issues in the establishment of advanced selling channels for services through a case study. It hopes that the present study could stimulate greater research in this area. 


\section{Endnotes}

[1] Formalization is the extent to which explicit rules and procedures regulate the behavior of the firms involved in the relationship (Dwyer and Oh, 1987).

[2] The fact that services are inseparable between production and consumption and perished immediately after would also mean that all services are technically sold in advance, even if it is a mere minutes in advance before consumption.

[3] Services are usually valued because it is required at a particular time e.g. a flight or a hotel room. Changing the time of consumption would alter the benefit and therefore the value to the customer. 


\section{REFERENCE}

Anderson, Erin (1985), "The Salesperson as Outside Agent or Employee: A Transaction Cost Analysis," Marketing Science, Vol.4 No. 3, pp234-254

----- and Weitz, Barton A. (1992), "The Use of Pledges to Build and Sustain Commitment in Distribution Channels," Journal of Marketing Research, Vol. 29, February, pp18-34

Anonymous (1995), "The Cruise Industry 1995", Cruise Industry News, Vol. 11, No. 6, March 31, p5

Bateson, John E.G. (1995), Managing Services Marketing: Text and Readings, $3^{\text {rd }}$ Edition, The Dryden Press, Orlando FL.

Bello, Daniel C. and Lohtia, Ritu (1995), "Export Channel Design: The Use of Foreign Distributors and Agents", Journal of Academy of Marketing Science, Vol. 23, No. 2, pp83-93

Bergen, Mark, Dutta, Shantanu and Walker Jr., Orville C. (1992), "Agency Relationships in Marketing: A Review of the Implications and Applications of Agency and Related Theories," Journal of Marketing, Vol. 56, July, pp1-24

Bloch M. and Segev, A. (1996), The Impact of Electronic Commerce on the Travel Industry, http://haas. berkley.edu/ citm

-----, Pigneur, Y. and Steiner, T. (1996), The IT enabled Extended Enterprise, Applications in the Tourism Industry, http://haas. berkley.edu/ citm
Burkart, A.J. and Medlik, S. (1981), Tourism: Past, Present and Future, Heinemann, UK

Clasen, Thomas F. (1991), "An Exporter's Guide to Selecting Foreign Sales Agents and Distributors," Journal of European Business, Vol. 3, Nov, pp28-32

Coase, Ronald H. (1937), "The Nature of the Firm", Economica, Vol. 4, pp386-405

Dahlstrom, Robert, Dwyer, F. Robert and Chandrashekaran, Murali (1995), "Environment, Structure and Performance in Interfirm Exchange", Journal of Businessto-Business Marketing, Vol. 2, No. 2, pp. 37-58

----- and Arne Nygaard (1999), "Ownership Decisions in Plural Contractual Systems," European Journal of Marketing, Vol. 33, No. $1 / 2$, pp59-87

Donald, Weinrach J., Mann, Karl, Robinson, Patricia A., and Pharr, Julia (1991), "Dealing with Limited Resources: A Marketing Challenge for Small Business", Journal of Small Business Management, Vol. 29, No. 4.

Dwyer, F. Robert and Sejo, Oh (1987), "Output Sector Munificence Effects on the Internal Political Economy of Marketing Channels", Journal of Marketing Research, Vol. 24, (Nov), pp. 347368

Erramilli, M.K. and Rao, C.P. (1993), "Service Firms International Entry Mode Choice: A Modified Transaction-cost Analysis Approach," Journal of Marketing, Vol. 57, Jul, pp19-38 
Ferguson, Robert (1997), "Far East: New Developments," Cruise Industry News Annual, $10^{\text {th }}$ Edition, New York: Cruise Industry News, pp121

Foster, D. (1985), Travel and Tourism Management, Basingstoke: Macmillan

Frey-Gaynor, Luisa (1993), "Unprecedented Growth in the Pacific Region", Cruise Industry News Quarterly, Fall, pp48-50

Frey-Gaynor, Luisa (1995), "Orient and South Pacific: Many Changes are in Store for this Warm-weather Cruising Alternative," Cruise Industry News Quarterly, Fall, pp75-79

Godsman, James G. (1994), "New Destinations and Added Capacities Fuel Opportunities" in Ward, Douglas (ed.)World Cruise Industry Review, Sterling Publications, UK, p19

Goodall, B. and Ashworth, G. (eds.) (1988), Marketing in the Tourism Industry: The Promotion of Destination Regions, CroomHelm, Beckenham Heide, Jan B. and George John (1988), "The Role of Dependence Balancing in Safeguarding Transaction-Specific assets in Conventional Channels," Journal of Marketing, Vol. 52, January, pp20-35

----- and ----- (1990), "Alliances in Industrial Purchasing: The Determinants of Joint Action in Buyer-Supplier Relationships," Journal of Marketing Research, Vol. 27, February, pp24-36 Jeuland, Abel P. and Shugan, Steven M. (1983), "Managing Channel
Profits", Marketing Science, Vol. 2

No. 3, Summer, pp239-272

Joskow, Paul L. (1987), "Contract Duration and Relation-specific Investments: Empirical Evidence from Coal Markets," American Economic Review, Vol. 77 No. 1, Mar, pp168-185

Klein, Saul, Frazier, Gary L., and Roth, Victor J. (1990), "A Transaction Cost Analysis Model of Channel Integration in International Markets," Journal of Marketing Research, Vol. 27, May, pp196-208

Lal, Rajiv (1990), "Improving Channel Coordination through Franchising", Marketing Science, Vol. 9, No. 4, pp299-318

Lee, Khai S. and Ng, Irene C.L. (2001), "Advanced Sale of Service Capacities: Impact of Price Sensitivity To Supply on Optimal Pricing And Capacity Allocations", Journal of Business Research, Vol. 54, pp219-225

Light, Donald (1986), "A Guide for New Distribution Channel Strategies for Service Firms", Journal of Business Strategy, Vol. 7, No. 1, Summer

Lovelock, Christopher (2000), Services Marketing: People, Technology, Strategy, $4^{\text {th }}$ edition, Prentice Hall, N.J

Lusch, Robert F. and Brown, James

R. (1996), "Interdependency, Contracting, and Relational Behavior in Marketing Channels", Journal of Marketing, Vol. 60, October, pp19-38

Lutz, Richard J. and Reilly, Patrick J. (1973), "An Exploration of the Effects of Perceived Social and

Ng, Irene C.L. (2006), "Establishing a Service Channel: A Transaction Cost Analysis of a Channel Contract between a Cruise Line and a Tour Operator," Journal Of Services Marketing, Volume 21, No. 7 
Performance Risk on Consumer Information Acquisition," in Ward, Scott and Wright, Peter (eds.) Advances in Consumer Research, Vol. 1, Association of Consumer Research, Urbana, IL, pp393-405

Middleton, Victor T.C. (1994), Marketing in Travel and Tourism, $2^{\text {nd }} \quad$ Edition, $\quad$ ButterworthHeinemann Ltd, U.K.

Master, Scott E. (1996), "Introduction" in Masten, Scott E (ed.) Case Studies in Contracting and Organization, .Oxford University Press, New York, pp3-25

Murray, K.B and Schachter, J.L (1990), "The Impact of Services Versus Goods on Consumers' Assessment of Perceived Risk and Variability," Journal of the Academy of Marketing Science, Vol. 18, winter, pp51-65

Murray, J.Y. and Kotabe M. (1999), "Sourcing Strategies of US Service Companies: A Modified Transaction Cost Analysis," Strategic Management Journal, Vol. 20, pp791-809

$\mathrm{Ng}$, Irene C.L. (1995a), "The Cruise Industry - A Spin Off From The Tourism Industry", Proceedings of the National Tourism and Leisure Conference, Kota Kinabalu, Sabah, Malaysia, May 11-12.

----- (1995b), "The Developing Far East Cruise Market", Cruise Industry News Quarterly, Fall, pp81

----- (1996), "Market Focus - South East Asia" in Cruise Industry News Annual, New York: Cruise Industry News, pp133-134

------, Wirtz, Jochen, and Lee, KhaiSheang, (1999), "The Strategic
Role of Unused Service Capacity," International Journal of Service Industry Management, Vol. 10, No. 2, pp211-238

-----, (2004), "The Pricing of Services: A Theoretical Framework", Proceedings of the 8th International Research Seminar in Services Management, 4-6 June 2004, La Londe, France

Ouchi, William G. (1979), "A Conceptual Framework for the Design of Organizational Control Mechanisms," Management Science, Vol. 25, No. 9, pp833848

Payne, Adrian (1993), The Essence of Services Marketing, Prentice Hall Europe

Peterson, Robert A., Sridhar Balasubramanian and Bart J. Bronnenberg, (1997), "Exploring the Implications of the Internet for Consumer Marketing," Journal of Academy of Marketing Science, Vol. 28, No. 1, pp168-174

Pitt, L.F., Berthon, P. and Berton, J.P. (1999), "Changing channels: The Impact of the Internet on Distribution Strategy," Business Horizons, Vol. 42, No. 2, pp19-28

Quelch, J.A. and Klein, L.R. (1996), "The Internet and International Marketing," Sloan Management Review, Vol. 37, No. 3, Spring, pp60-75

Rindfleisch, A. and Heide, J,B. (1997), "Transaction Cost Analysis: Past, Present and Future applications," Journal of Marketing, Vol. 61, Oct, pp30-54

Root, Franklin R. (1987), Entry Strategies for International 
Markets, First Edition, Lexington, MA: Lexington Books

Seaton, A.V. and Bennett, M. M. (1996), The Marketing of Tourism Products: Concepts, Issues and Cases, International Thomson Business Press, U.K.

Shugan, Steven M. and Xie, Jinhong (2000), "Advance pricing of services and other implications of separating purchase and consumption," Journal of Service Research, 2 (3): 227-239

Simon, Herbert A. (1957), Models of Man, Social and Rational, Wiley, New York

----- (1961), Administrative Behavior, $2^{\text {nd }}$ Edition, Macmillan, New York

Stone, Merlin (1990), "Marketing Strategies for Leisure Services", Long Range Planning, Vol. 23, No. 5 , pp. $76-90$

Telser, Lester G. (1980), "A Theory of Self-Enforcing Agreements", Journal of Business, Vol. 53, pp27-44

Verity, J.W. and Hoff R.D. (1994), "The Internet: how it will change the way you do business," Business Week, November 14, pp80-8

Warner, Maggie (1994), "Cruising Down-Under", Proceedings of the $3^{\text {rd }}$ Seatrade Asia-Pacific Cruise
Convention in Singapore, December

Williamson, Oliver E. (1985), The Economic Institutions of Capitalism, Free Press, New York ----- (1989), "Transaction Cost Economics," in Schmalensee, R. and Willig, R. (eds) Handbook of Industrial Organization, Vol.1, North-Holland, Amsterdam, pp135-182

(1991), "Comparative Economic Organization: The Analysis of Discrete Structural Alternatives," Administrative Science Quarterly, Vol. 36, pp269-96

Wynne, Clive, Pierre Berthon, Leyland Pitt, Michael Ewing and Julie Napoli, (2001), The Impact of the Internet on the Distribution Value Chain: The Case of the South African Tourism Industry," International Marketing Review, Vol. 18, No. 4, pp420-431

Xie, Jinhong and Shugan, Steven M. (2001), "Electronic Tickets, Smart Cards and Online Prepayments: When and How to Advance Sell," Marketing Science, 20, 3, Summer, 219-243

Zeithaml, Valarie A. and Bitner, Mary Jo (2000), Services Marketing: Integrating Customer Focus across the Firm, $2^{\text {nd }}$ edition, McGraw Hill 


\section{Table 1}

\begin{tabular}{|ll|}
\hline Day & Port \\
\hline Sunday & Port Klang (PKL) \\
Tuesday & Penang (PEN) \\
Wednesday & Phuket (HKT) \\
Thursday & Penang \\
Friday & Penang \\
& (Port Klang) \\
Saturday & Port Klang \\
\hline
\end{tabular}

* Occasionally the vessel returns to Port Klang on Friday instead of Saturday 


\section{Table 2}

\section{Typical Fly-Cruise-Tour Itinerary for the Australian Market}

\section{Day 1}

AM: Fly Australia - Kuala Lumpur

PM: Day Excursion. Board "The Asian Princess" for a cruise to Penang Day 2

AM: Arrive Penang. Shore Excursion in Penang.

PM: Return to ship in evening. Cruise to Phuket.

Day 3

AM: Arrive Phuket. Disembark. Check in to Phuket hotel.

PM: At leisure

Day $4-10$

At leisure/Tour of Phuket Island

Day 11

PM: Board the Asian Princess. Cruise to Penang

Day 12

AM: Arrive Penang. Transfer to Airport Flight back to Australia.

(Extensions of stay are possible) 


\section{Figure 1: Map of Cruise Routes}

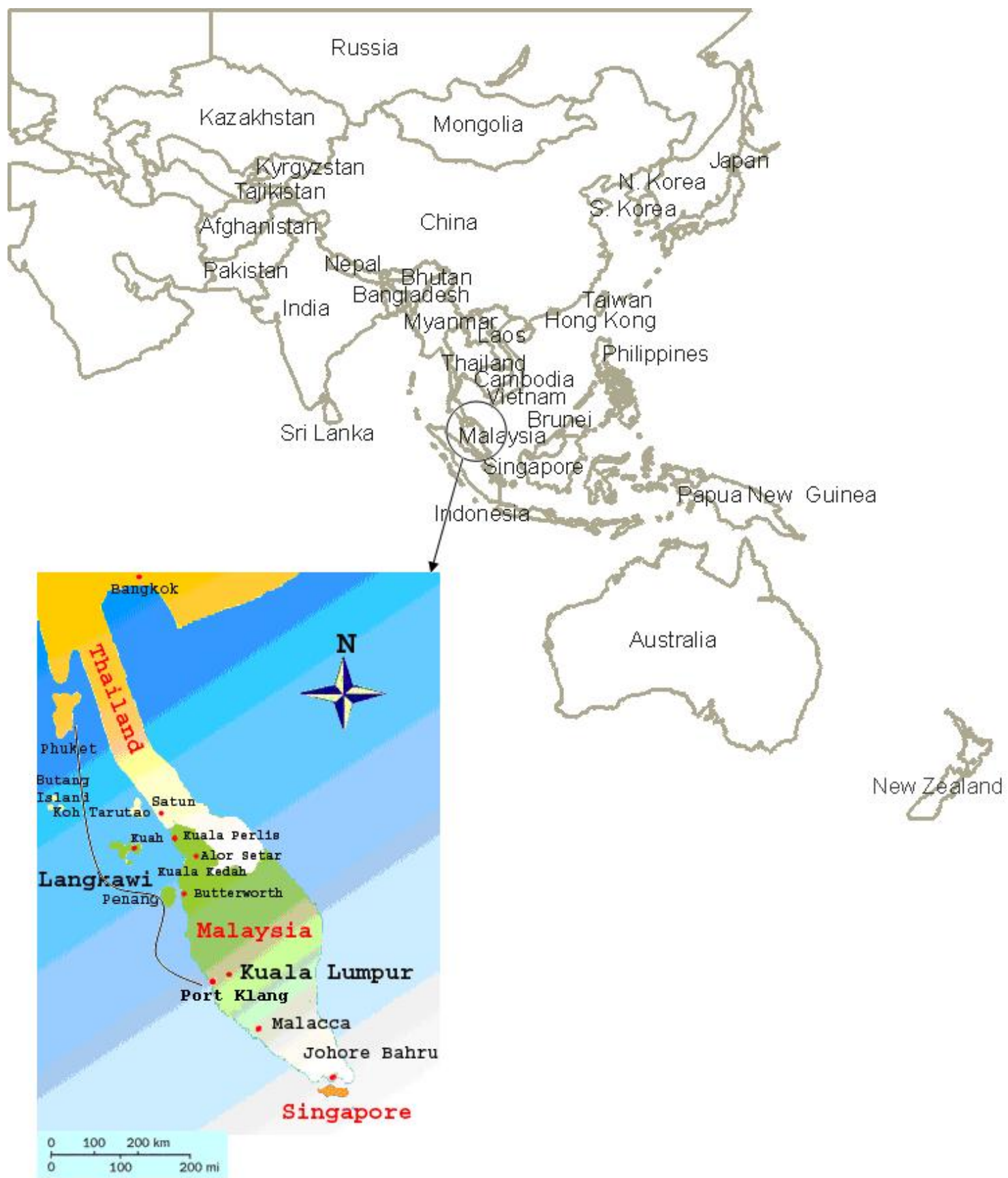

Ng, Irene C.L. (2006), "Establishing a Service Channel: A Transaction Cost Analysis of a Channel Contract between a Cruise Line and a Tour Operator," Journal Of Services Marketing, Volume 21, No. 7 